\title{
The Inquiry of Storytelling Narrative in the Museum Display
}

\author{
Design \\ Yutong $\operatorname{Han}^{1 *}$ \& Chuanhong $\mathrm{Xu}^{2 *}$ \\ ${ }^{1}$ Shanghai University of Engineering Science, 333 Long Teng Road, Shanghai, China \\ *Han Yutong, E-mail: 626392459@qq.com
}

Received: March 17, 2017

Accepted: March 22, 2017

Online Published: April 13, 2017

doi:10.22158/wjssr.v4n2p114

URL: http://dx.doi.org/10.22158/wjssr.v4n2p114

\begin{abstract}
This article starts from space story construction, display scene design and the "people-oriented" experience design direction, combines with quality cases that leading the world museum display design, discusses how to use the storytelling narrative into museum display design. The paper will help better promote the plot development between space and exhibits, exhibits, people and exhibits, optimize the social education function of traditional museum, and spread exhibition information more effectively.
\end{abstract}

Keywords

story, museum display, scene, experience design

\section{Introduction}

The so-called "story" is to tell audience about a meaningful event in a narrative way. It comes from productive labor and material civilization of mankind, emphasizes continuity of story's fantastic twists during the narrative process, and gives vivid description for the story to render the whole atmosphere. Narrator himself wants to convey certain social pattern and value concept through this. From the perspective of narratology, it is easy to find that modern museum plays an important role in helping visitors understand cultural heritage and the construction of urban cultural identity. And its internal space display design will promote the whole development and evolution of the story till the end.

\section{Results and Discussio}

\subsection{Story Construction}

In constructing narrative exhibition space, current museums should determine the specific story clues to guide the audience visit in accordance with the main exhibition line, to expand in given linear narrative sequence. Fantastic twists design in exhibition space should be set up according to the variation of exhibits, and then complete the scenario transformation, promote audience's emotion of enjoying exhibition. In general, the story structure should includes characteristics such as beginning, development, 
climax and the end. Stories of the museum exhibition space constitutes the specific environment of exhibits display, people's activities in the space also further promote the development of story. In overall display design planning, it should be based on the space size and content to arrange the number and location of story points. The more story points design drives the rhythm of display more quickly, on the other hand, it is contrary.

The Jewish Museum in Berlin which is located in Berlin at the junction of the fifth avenue and 92th street is a typical case of telling the history of Jews drifting from place to place combined with narrative story. It is built to memory the six million Jews that died in the Third Empire Period, and it shows historical cultural relics and life records of Jews in Germany for nearly two thousand years. In the museum display design, space becomes a narrator in telling the miserable history of Jewish people. D. Libes kind designed three main tunnels that represent Jewish destiny at the end of the museum underground entrance, which force audience to choose in the three axis. It suggests three kinds of fate of Jews, respectively representing "Dead", "Escape" and "Suffer".

The first axis of exhibition hall was called the "Axis of the Massacre". When you opened the heavy metal door, what presents in front of you is a dark, claustrophobic space that you can only see a ray of light leaking from cracks at the top. Viewers at this time experience just like falling in a deep well bottom, clearly feel being put in the gas chambers, the loneliness and despair of waiting for death. Another axis is known as the "Axis of Exile", it leads to the outdoor Hoffman Park, with 49 concrete square columns that rising at 20 degree angles. Column spacing is so narrow that can only go through one person, especially the slope on the turning makes people struggling, so as to show the hard living course of Jews fleeing and drifting outside the territory. Going along the channel to the exhibition hall, it comes the third axis the "Axis of Continuity", guests will be involved in a disorder of time and space unexpectedly. Recurring black wall compresses and deforms the space order again to stimulate the senses of audience, which brings powerful visual impact. Designers take this to suggest all kinds of joys and sorrows of ancient Jewish people in the Nazi Era. When the exhibition comes to the end, a loud noise of closing the door adds audience more grief. Rugged icy space in the museum brings audience into exquisite vivid historical story. Since the moment stepping into the museum space entrance, the story begins, generates and develops in the process of visitor walking, until the end at the whole exhibition exit.

\subsection{Emotion in Scene}

Wonderful stories help audience quickly capture the key points of exhibition theme. Exhibition space exhibits tells wonderful events from the combination of a series of small associated stories. Story involved make simple items send out the voice of the narrator instead of curators, which affects the feeling and mood of audience. Эйзенштейн once referred in the Неравнодушная природа, "when songs and legends have been died out and a dead nation has no more trace, the place where people lived and events happened can often tell everything" (Note 1). Narrative of the main exhibits in the museum exhibition space may better help audience establish the historical visual image, that close to the past 
social civilization.

The British Museum in London has been two hundred years until now; it is the world's most magnificent and oldest comprehensive museum that is ranked top four in the world. In 2003 to celebrate the 250th anniversary, the British museum was completed the transformation of the oldest King's Library and was set up a long-term exhibition-the enlightenment: to explore the world of the 18th century, open to the public. Exhibition space still retains the traditional state of museum of the 19th century under carefully transformation and design. Display followed old storefront of the British library, cultural relics exhibits together with the storefront tell us about the history, involving each audience to experience the significance of the Enlightenment. When using space narrative expression, exhibits unified with one theme not only shows the historical origin and academic value of exhibits specifically, but also digs and conveys the connection between exhibits.

In September 2016, exhibition in Beijing Capital Museum “Three Capitals of Yuan Dynasty” effectively utilizes storytelling narrative on the cultural relics display design, which interprets ancient wisdom for audience, shows a panoramic and vibrant picture of social life in Yuan Dynasty. Ceremonial figurines in the glass display shows that 18 figurines arranged in order according to the procession of emperors and nobility, black horse camel drum and horse drum paving the way in front, and surrounded by army guard. It shows royal travel scene the relationship between the characters. It changes the single form of traditional museum display, the scene narrative mode gives more stories and expression.

\subsection{Emotion on People}

People in the exhibition space activities as dynamic factor in the narrative increasingly constitutes an important part of museum display design. A growing number of exhibition halls are beginning to use digital media or virtual image technology to realize 4D display exhibits. Shanghai Film Museum, as an outstanding representative of industry museums, integrates interior design display and activities visiting and experiencing together, vividly interprets filmmakers, film stories and the story behind film. On the screen of "Nanjing Road under the Mercury Lamp" in the "Light Memory" exhibition, in addition to exhibit classic shooting scenes such as "the Road Angel", it also recreates the Hujiang Photo Studio, windows of the New Department Store, Feida Cafes, and other famous business street scenes of old Shanghai, takes viewers go through time, closely experiences the bustling and charm that often performed in Shanghai film and television. Multi-point touch technology from a distance in this device emanates unique charm, it greatly promotes the competitive consciousness of the viewer through the movie encyclopedia q \& a way or making dialogue with audience. It not only shortens people's intimacy with film, but also stimulates exhibitors' thirst for knowledge. Besides helping to broaden the information dissemination channels of exhibits, deepen exhibition experience, dynamic display also makes up for the restricted condition of physical objects or images exhibits.

Dynamic display is far more than this, experiential story model pays more attention to people themselves.

"Experiential Participation" as a branch of display design story line, establishes a new humanistic design 
concept. The Alamo War Memorial in the United States also recruited volunteers when displayed, volunteers are required to wear war clothes, hold weapon at that time and do regular real scenario simulation, visitors in such an environment and performance will appreciate the special historical time profoundly.

\section{Conclusion}

Museum display starts from focusing on the space form to the relationship between environment and space human and exhibits, then develops to pay attention to emotion rendered from the exhibits. In addition to meet the needs of display and exhibits list, the space display of modern museum also should meet the people's emotional requirements to the exhibition space. The scenario identity is formed and expressed by display design stories. Narrative description of exhibition space becomes detailed, which expands people's emotional experience, it is the ultimate goal of this technique turned to the immersion museum display design.

\section{Acknowledgement}

I would like to express my gratitude to all those who have helped me during the writing of this thesis. I gratefully acknowledge the help of my supervisor Professor Chuanhong Xu. I do appreciate his patience, encouragement, and professional instructions during my thesis writing. Last but not the least, my gratitude also extends to my family who have been assisting, supporting and caring for me all of my life.

\section{References}

Li, N. X. (2015). The Sequence Analysis of Museum Exhibition Space based on Spatial Narrative. Furniture and Interior Decoration, 2015(8), 82-83.

Liu, J. Y. (2012). Space and Rhythm of Historical Exhibition-Structuralism Narratology Perspective. Chinese Museum, 2012(3), 84-89.

Tong, X. M. (2013). Observation of Spatial Experience—Plot Design of Display Space. Art Education, 2013(7), 172-173.

Zhu, J. J. (2010). Analysis on the Plot Points of Modern Museum Exhibition Space Design. Coastal Enterprises and Science \&Technology, 2010(5), 93-95.

\section{Note}

Note 1. Эйзенштейн. Неравнодушная природа [M]. Fulan (trans.). Beijing: China Film Press, 1996(211). 